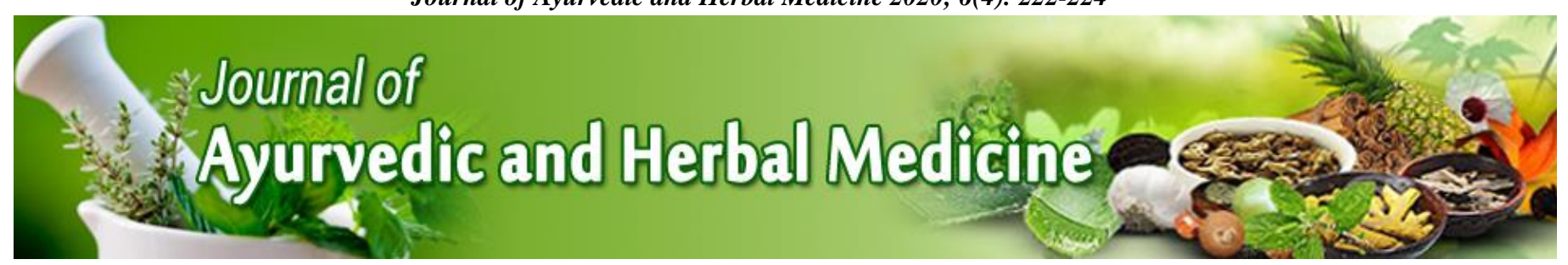

\section{Review Article}

ISSN: 2454-5023

J. Ayu. Herb. Med. 2020; 6(4): 222-224 (C) 2020, All rights reserved www.ayurvedjournal.com Received: 08-10-2020 Accepted: 18-01-2021
*Corresponding author: Dr. Mayoori $S$

PG Scholar, Department of Agadatantra, Govt. Ayurveda College Thiruvananthapuram, Kerala

Email: mayoorivasudev@gmail.com

\title{
A Review Article on Toxicity Induced Hepatocellular Carcinoma: Through Gara Visa perspective
}

\author{
Mayoori S' ${ }^{1}, C K$ Krishnan Nair ${ }^{2}$ \\ 1 PG Scholar, Department of Agadatantra, Govt. Ayurveda College Thiruvananthapuram, Kerala, India \\ 2 Professor \& H.O.D Department of Agadatantra, Govt. Ayurveda College Thiruvananthapuram, Kerala, India
}

\section{ABSTRACT}

Hepatocellular carcinoma is the most common primary malignancy of liver in adults and is the common cause of death in people with cirrhosis ${ }^{[1]}$. The majority of this disease occurs over pre-existing chronic liver cirrhosis but the increased changes in living conditions, food habits and sedentary life style has emerged the disease into a silent killer category independent of cirrhosis. The present modifications in food habits, drug induced toxicity and other environmental toxicity has led to a dramatic rise in HCC even in non-alcoholics. The symptoms and pathogenesis in HCC can be eventually be correlated with Garavisa Lakshana, Samprapthi and the judicious application of its treatment in Ayurveda can concrete a new path in its treatment aspect.

Keywords: Toxicity induced HCC, Gara visa.

\section{INTRODUCTION}

The word Gara is derived from the root word 'Gru' with 'Ach' suffix that means 'to deglute' or 'could be degluted'.

As per the ancient literature Gara is considered to be a form of Krithrima Visha ie a combination of two or more poisonous (artificial sweetners, flavouring agents) or non-poisonous substance (Virudha Ahara) [2] which exerts a toxic effect on body by vitiating Dhatus.

This includes different body parts of insects, menstrual blood, urine, faeces etc of human and animal origin. Medicines having diametrically opposing action on the same physiological system, Virudhahara, ashes of metallic or mineral origin, poisons of low potency etc can also be included under gara ${ }^{[3]}$. Charaka Acharya classified this under Samyogaja Visa and is Kalaantara Vipaki since it takes long time for this type poison to get metabolised. Susrutha Acharya explained this concept in Keeta Kalpa Adhyaya with an entirely different concept of transdermal application of Gara Yogas ${ }^{[4]}$.The Vishishta Guna of Gara ie Apaki and the cumulative period of toxicity is about 15 to 30 days are explained by Madhukosa and Yogaratnakara respectively. The Kerala Visha Chikilsa Granthas expounded this under the reference of Kaivisham with its prime motive as Vashyartham \& Vairartham.

\section{PROBABLE MODE OF ACTION}

Basically it depends on combination of poison, dose and route of administration. If ingested it produces systemic toxicity and if applied externally it acts trans-dermally. As per the classification, Gara is of two types Savisha Samyogaja and Nirvisha Dravya Samyogaja. If the combination is Nirvisha Samyogajam it is not metabolised properly and later produce defective biotransformation triggering in basic pathologic reaction as like in Virudhaahara.

\section{Samprapthi}




\section{Gara Visa concepts in Toxicity induced Hepatocellular carcinoma}

Hepatocellular carcinoma is the primary malignancy of liver. It is the third leading cause of cancer death world-wide. Annual mortality and incidence are virtually identical due to its high case fatality rate. Its incidence in India among male accounts for 0.7 to 7.5 and for female 0.2 to 2.2 per 100000 population per year ${ }^{[5]}$.

The major causative factors for HCC are

- Hepatitis B \& C infections

- Non-alcoholic Steatohepatitis

- Alcohol induced hepatitis

- Aflatoxin toxicity etc

Aflatoxins are food contaminants produced by fungi Aspergillus flavus \& Aspergillus parasiticus. The main food sources of its contamination are maize, dried fruits, meat, spices, oil seeds and milk.

The Aflotoxin toxicity detected in milk by FSSAI milk survey in recent days reminisces the importance of daily toxic exposure to human beings ${ }^{[6]}$. Both toxicity and carcinogenicity is being studied experimentally for which acute aflotoxicosis results in death. Chronic aflatoxicosis mainly includes prolonged pathologic changes in liver including cancer and immune suppression. The basic mechanism of action of this toxicity includes tumour promotion or progression ie activation of proto oncogenes and mutation in tumour suppressor genes $p 53^{[7]}$.

\section{PATHOGENESIS OF HCC}

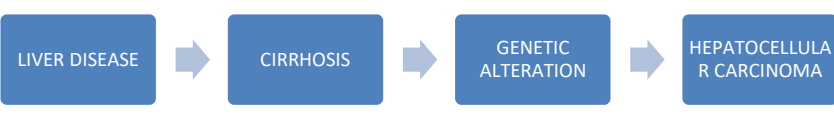

\section{Contributing factors ${ }^{[8]}$}

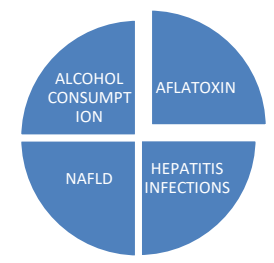

\begin{tabular}{|l|l|}
\hline Hepatocellular carcinoma ${ }^{[9]}$ & Garavisa \\
\hline weight loss reduced appetite nausea \& vomiting & Krsha Alpaagni \\
\hline Fever & Kasa Swasa Jwaraadi \\
\hline Right upper quadrant pain & Pratiloma gati of Vayu \\
\hline Anemia bleeding tendency & Pandu \\
\hline Feeling of exhaustion & Durbala Alasa Deena Vak \\
\hline Ascites & Mahodara \\
\hline Hepatomegaly \& splenomegaly & Yakrt Pliha Roga \\
\hline Ankle edema \& feeling of fullness & $\begin{array}{l}\text { Sopham Adhmana Suska } \\
\text { Pada Kara, Kshayi }\end{array}$ \\
\hline Jaundice chalky white stools \& darker urine & \\
\hline Pruritis & \\
\hline $\begin{array}{l}\text { Hard to detect as symptoms don't appear until } \\
\text { progress significantly }\end{array}$ & Chirat Chiratharat Cha Tat \\
\hline
\end{tabular}

Journal of Ayurvedic and Herbal Medicine|October-December|2020

\section{Proposed treatment plans}

Here we can adopt treatment principles of both Dooshivisha and Gara Visa since the disease remain latent in the body for a long time and manifest symptoms at its advanced stage.

Yat Sthavaram Jangamakrithrimam Va Dehadasheshamanirgatam... Dushivishamupaithi ${ }^{[10] .}$

The treatment includes

Shodhana Chikilsa-

- Vamanam - to expel out the unmetabolised toxic substances in the stomach.

- Virechanam - Biopurification that enhances toxicity elimination at cellular level and to help in stopping mutation process through actions at check points.

\section{Samana Chikilsa}

- Moorvadi Churnam - help in metabolic correction through action at Dhatu level (Dhatvagni Mandya) as liver is the primary target organ or toxicity.

- Dooshivishari Agadam- while analysing the drugs of the yoga the main ingredient piperine help in inhibiting the cytochrome p450 and enhances the bioavailability of drug. Almost all the drugs have anti-cancerous properties with some hepatoprotective in nature such as Kushta Eladi. The probable mode of action as explained by Susrutha Acharya in Nibandha Sangraha teeka as samana and prasadana ie

'Anirhathasya Vishaavasheshasya Samshamanartham' 'Visha Dooshitha Dhatunam Prasamanrtham'.

\section{DISCUSSION}

The modern treatment options for HCC are very limited since $70 \%$ of patients are inoperable due to its advanced stage and may be associated with any underlying liver pathology. The treatment modalities mainly include surgery i.e. liver resection or transplantation, local ablative therapies, radiotherapy, chemotherapy etc. and supportive care. Among these radiotherapy, chemotherapy are generally ineffective. Hence newer treatments and early diagnosis and intervention is a need for a better prognosis in such cases.

Ayurvedic treatment options are very unique for disease prevention and to disrupt its further progression. The basic principle of Ayurveda Chikitsa lies in Agni correction or Amapachana what we can be modernly say it as metabolic correction. Vaiswanara Choornam is one among those that helps in correcting Agni there by correcting the metabolic function of liver. In fact Amapachana or elimination of toxicity from our body is the basic of all our treatments and Agadatantra is a branch of our science contributing formulations having magical actions. Various combinations of drugs have proven its hepato-protective activity and also found helpful in hepatocellular regeneration. In Madatyaya Chikitsa, enormous amount of Yogas has been elaborately mentioned that facilitates the quick elimination of acetaldehyde and preclude alcohol induced liver injury. 
The best part of our treatment principle is that not a single choice of drug is effective in every condition or in every individual and it is the Yukthi of Vaidya to find out the best medicine considering the RogaRogi Avastha and Prakrthi.

The present lifestyle modifications and diet contribute a lot in diseases like HCC and our role in its treatment can be designed from its grass root level itself. Following regimens of Dinacharya and Rtucharya and Shodhana Chikilsa (Yadha Kalam) helps in mitigating Dosha and elimination of toxicity in our body. Yakrt Roga Chikitsa in Ayurveda mainly includes Pitha Dosha Shamana, Raktha Prasadana and drugs mentioned in the treatment mostly are Shothahara, Anulomana and Dipana- Pachana which help in correcting Agni and Pitha Dosha in our body. The drugs that we commonly use in Yakrt Vikaras like Amalaki, Punarnava, Katuki, Guduchi, Bhumi-amalaki, Bhunimba etc are both scientifically proven as anti-cancerous and hepato-protective.

The basic treatment principles in Gara Visa Chikitsa along with Yakrt Roga Samana drugs prudently in combination can eradicate many of the diseases in liver that begin with a simple grade 1 fatty liver and end up with some cirrhosis or carcinoma.

\section{CONCLUSION}

Supportive care in patients diagnosed with HCC and intervention in early diagnosed cases with $\mathrm{HCC}$ and its preventive aspects might be a better option as far as our treatment modalities are concerned. The preventive and therapeutic applications and life style alteration in Ayurveda on cancer is incredible especially on considering the metabolic correction and hence its exploitation should be further promoted.

\section{REFERENCES}

1. Tholey D. Hepatocellular Carcinoma - Liver and Gallbladder Disorders [Internet]. MSD Manual Consumer Version. MSD Manuals; [cited 2020Mar15]. Available from: https://www.msdmanuals.com/home/liverand-gallbladder-disorders/tumors-of-the-liver/hepatocellular-carcinoma

2. Vagbhata, AshtangaHrdaya (English Translation) Vol 1 translated by K.R Srikantha Murthy, Varanasi: Chaukhambha Krishnadas Academy, $7^{\text {th }}$ Edition, 2010. Sutrasthana 7/29.p.114

3. Vagbhata, AshtangaHrdaya (English Translation) Vol 3 translated by K.R Srikantha Murthy, Varanasi: Chaukhambha Krishnadas Academy, $7^{\text {th }}$ Edition, 2010. Utharasthana 35/48.p.336

4. Sushruta, Sushruta Samnhita (English Translation) Vol 2 translated by K.R Srikantha Murthy, Varanasi: Chaukhambha Orientalia, Edition reprint, 2012. Kalpasthana 8/24.p.481

5. Acharya SK. Epidemiology of hepatocellular carcinoma in India [Internet]. Journal of clinical and experimental hepatology. Elsevier; 2014 [cited 2020Mar10]. Available from: https://www.ncbi.nlm.nih.gov/pmc/articles/PMC4284206/

6. Ambwani MV. FSSAI Milk Survey finds $7 \%$ samples unfit for consumption [Internet]. @businessline. The Hindu BusinessLine; 2019 [cited 2020Mar10]. Available from: https://www.thehindubusinessline.com/economy/fssai-milk-survey-finds7-samples-unfit-for-consumption/article29737315.ece

7. Streba CT, Vere CC, Florescu IRandND. Introductory Chapter: Etiology and Pathogenesis of Hepatocellular Carcinoma [Internet]. IntechOpen. IntechOpen; 2018 [cited 2020Mar8]. Available from: https://www.intechopen.com/books/hepatocellular-carcinoma-advancesin-diagnosis-and-treatment/introductory-chapter-etiology-andpathogenesis-of-hepatocellular-carcinoma
8. Chu Y-J, Yang $\mathrm{H}-\mathrm{I}, \mathrm{Wu} \mathrm{H}-\mathrm{C}$, Lee $\mathrm{M}-\mathrm{H}$, Liu J, Wang L-Y, et al. Aflatoxin B1 exposure increases the risk of hepatocellular carcinoma associated with hepatitis C virus infection or alcohol consumption [Internet]. European journal of cancer (Oxford, England: 1990). U.S. National Library of Medicine; 2018 [cited 2020Mar28]. Available from: https://www.ncbi.nlm.nih.gov/pmc/articles/PMC5895495/

9. Dimitroulis D, Damaskos C, Valsami S, Davakis S, Garmpis N, Spartalis E, et al. From diagnosis to treatment of hepatocellular carcinoma: An epidemic problem for both developed and developing world [Internet]. World journal of gastroenterology. Baishideng Publishing Group Inc; 2017 [cited 2020Feb12]. Available from: https://www.ncbi.nlm.nih.gov/pmc/articles/PMC5550777/

10. Sushruta, Sushruta Samhita (English Translation) Vol 2 translated by K.R Srikantha Murthy, Varanasi: Chaukhambha Orientalia, Edition reprint, 2012. Kalpasthana 2/25.p.423

\section{HOW TO CITE THIS ARTICLE}

Mayoori S, Krishnan Nair CK. A Review Article on Toxicity Induced Hepatocellular Carcinoma: Through Gara Visa perspective. J Ayu Herb Med 2020; 6(4):222-224. 